\title{
A rare case of secondary syphilis presenting with extensive cutaneous nodules and generalised lymphadenopathy
}

\author{
Funda Tamer $^{1}$ (iD, Mehmet Eren Yüksel ${ }^{2}$ iD , Gülşah Akgül ${ }^{3}$ (iD
}

${ }^{1}$ Gazi University School of Medicine, Department of Dermatology, Ankara, Türkiye

${ }^{2}$ Aksaray University School of Medicine, Department of General Surgery, Aksaray, Türkiye

${ }^{3}$ Ufuk University School of Medicine, Department of Pathology, Ankara, Türkiye

Funda TAMER, Asst. Prof. Mehmet Eren YÜKSEL, Asst. Prof. Gülşah AKGÜL, MD

İletişim: Funda Tamer Gazi University School of Medicine, Department of Dermatology, Ankara, Türkiye Tel: +903122026129

E-Posta: fundatmr@yahoo.com

Gönderilme Tarihi : 15 Nisan 2019

Revizyon Tarihi : 24 Temmuz 2019

Kabul Tarihi $\quad$ : 25 Temmuz 2019
Abstract

Syphilis is an infectious disease caused by the spirochete Treponema pallidum. Syphilis is divided into clinical stages including primary, secondary, latent and tertiary syphilis. Secondary syphilis can present with various mucocutaneous lesions and multisystem involvement. Since it can mimic many other diseases, syphilis is known as 'the great imitator'. However, secondary syphilis with nodular lesions is very rare. Moreover, nodular secondary syphilis can be misdiagnosed as syphilitic nodules of the tertiary stage. Hereby, we report an unusual presentation of secondary syphilis characterized by extensive erythematous nodules and generalised lymphadenopathy in an immunocompetent 39-year-old Caucasian male patient.

Keywords: Cutaneous, Lymphadenopathy, Nodule, Secondary, Syphilis, Treponema pallidum

Yaygın kutanöz nodüller ve generalize lenfadenopati ile seyreden nadir bir sekonder sifilizli olgu

Özet

Sifiliz, bir spiroket olan Treponema pallidum' un neden olduğu enfeksiyon hastalığıdır. Sifiliz primer, sekonder ve tersiyer sifiliz olmak üzere klinik evrelere ayrılır. Sekonder sifiliz çeşitli mukokutanöz lezyonlar ve multisistem tutulumu ile seyredebilir. Sifiliz birçok hastalığı taklit edebileceğinden 'büyük taklitçi' olarak bilinir. Ancak nodüler lezyonlarla seyreden sekonder sifiliz çok nadirdir. Bununla birlikte nodüler sifiliz tersiyer sifilizin nodülleri ile de karıştırılabilir. Burada, yaygın eritemli nodüller ve generalize lenfadenopati ile karakterize nadir görülen sekonder sifiliz bulguları olan 39 yaşında immünkompetan bir hasta sunduk.

Anahtar Kelimeler: Kutanöz, Lenfadenopati, Nodül, Sekonder, Sifiliz, Treponema pallidum

yphilis is a systemic infectious disease caused by the spirochete Treponema pallidum. Syphilis usually presents with several clinical manifestations. Therefore, syphilis can mimic many other systemic and cutaneous diseases. The clinical stages of the disease are primary, secondary, latent and tertiary syphilis (1). The hematogenous and lymphatic dissemination of the spirochetes leads to the secondary stage of syphilis. Secondary syphilis usually presents with generalised, asymptomatic, squamous papules (2). Macular, maculopapular, annular, lenticular and copper-colored, infiltrated corymbose lesions have also been described. However, nodular secondary syphilis is a very rare condition $(1,2)$. It has been suggested that secondary syphilitic nodular lesions might occur either as a result of a specific hypersensitivity reaction to the treponemal infection or they might be the sign of the transition to the tertiary phase (2). Hereby, we report a 39-year-old Caucasian male patient with secondary syphilis presenting with erythematous nodules and generalised lymphadenopathy. 


\section{Case Report}

A 39-year-old Caucasian male presented with an eightweek history of asymptomatic, erythematous extensive skin eruption. The patient stated that he had sore throat, fatigue, muscle ache and pain during urination ten weeks ago. The lesions developed five days after the initiation of oral ciprofloxacin $500 \mathrm{mg}$ twice daily. The patient was treated with oral desloratadine $5 \mathrm{mg} /$ day, oral methylprednisolone $16 \mathrm{mg} /$ day and topical betamethasone dipropionate ointment $0.05 \%$ twice daily for a week. However, no clinical improvement was achieved. The past medical history and family history were both unremarkable. The patient denied any allergies and prior sexual intercourse. The patient also stated that he had negative HIV testing four weeks ago. Dermatological examination revealed multiple, erythematous, firm papules and nodules on the face, neck, trunk, arms and thighs. Some of the nodules were either squamous or surrounded by erythema (Figures 1, 2).

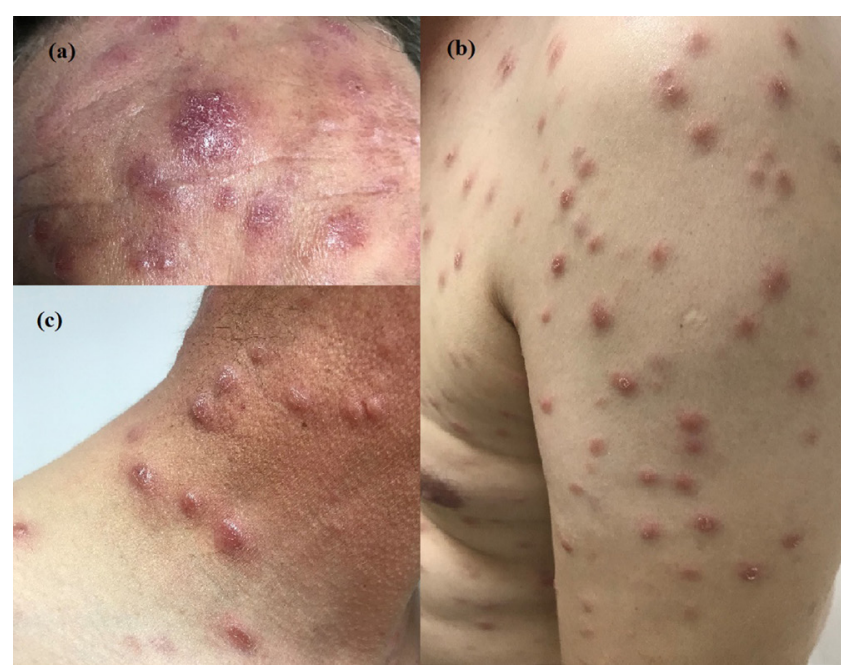

Figure 1. Erythematous papules and nodules on the forehead (a) left arm (b) and neck (c).

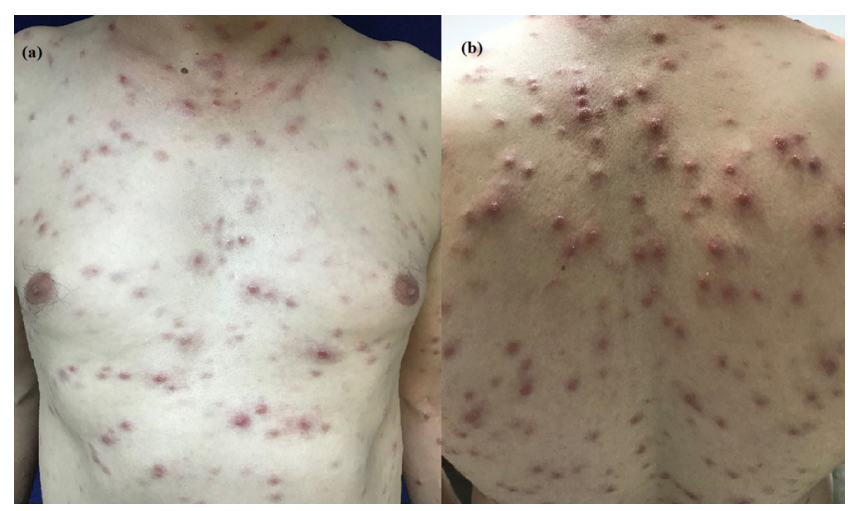

Figure 2. Erythematous papules and nodules on the chest (a) and back (b).
The neurological examination did not reveal any abnormal findings. A complete blood count revealed a mild monocytosis. The percentage of monocytes (MO) was 15.3 (reference range: $0-12 \%)$. The absolute MO count was $1.06 \times 10^{3} / \mu \mathrm{L}$ (reference range: $0-0.9 \times 10^{3} / \mu \mathrm{L}$ ). The chemistry panel including alanine aminotransferase, aspartate aminotransferase, total bilirubin, direct bilirubin, creatinine and antistreptolysin $\mathrm{O}$ titer were all within normal limits. However, the serum level of alkaline phosphatase (ALP) was $216 \mathrm{U} / \mathrm{L}$ (reference range: 30-150 U/L) and gamma-glutamyl transferase (GGT) was $259 \mathrm{U} / \mathrm{L}$ (reference range: 7-64 U/L). Moreover, the sedimentation rate was $78 \mathrm{~mm} / \mathrm{h}$ (reference range: $0-15 \mathrm{~mm} / \mathrm{h}$ ). Serum level of C-reactive protein was $59 \mathrm{mg} / \mathrm{L}$ (reference range: 0.01-5 $\mathrm{mg} / \mathrm{L})$. Serum levels of herpes simplex virus type 1 (HSV-1) IgM, HSV-2 IgM and HSV-2 IgG were negative. However, HSV-1 IgG was $117.38 \mathrm{RU} / \mathrm{mL}$ (negative $<16$; positive $>22$ $\mathrm{RU} / \mathrm{mL}$ ). The venereal disease research laboratory (VDRL) test was positive at a titer of $1 / 256$. In addition, the Treponema pallidum haemagglutination (TPHA) test was positive. Serum levels of hepatitis B surface antigen, antibodies against hepatitis $C$ virus, hepatitis $B$ virus and human immunodeficiency virus (HIV) were all negative. The ultrasonographic evaluation revealed grade I hepatosteatosis and multiple reactive lymph nodes in the neck, axilla and the groin. The largest lymph node size was $27 \times 11$ $\mathrm{mm}$ in the right axilla, $30 \times 12 \mathrm{~mm}$ in the left axilla, 22×10 $\mathrm{mm}$ in the right groin, $35 \times 14 \mathrm{~mm}$ in the left groin, $26 \times 10$ $\mathrm{mm}$ in the right submandibular area, $25 \times 7 \mathrm{~mm}$ in the left submandibular area, $25 \times 10 \mathrm{~mm}$ in the right jugular area and $17 \times 7 \mathrm{~mm}$ in the left jugular area. A skin biopsy was performed from an erythematous nodule on the upper back. The histopathological examination revealed epidermal parakeratosis, spongiosis, microabscess formation, basal vacuolar degeneration and lichenoid inflammatory infiltration of lymphocytes, plasma cells and polymorphonuclear leukocytes. Moreover, perivascular, interstitial and perifollicular non-caseating granulomatous inflammation was observed in the superficial and deep dermis (Figure 3).

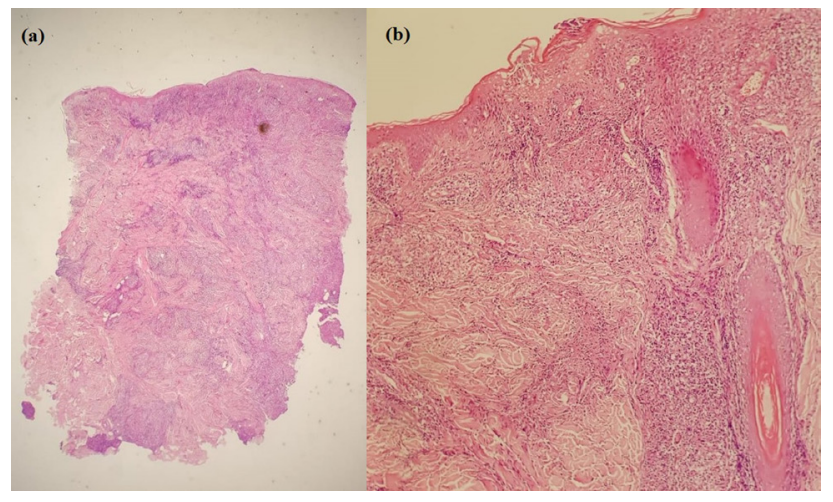

Figure 3. Non-caseating granulomatous inflammation in the superficial and deep dermis (H\&Ex2) (a) parakeratosis, spongiosis, basal vacuolar degeneration and microabscess formation (H\&Ex10) (b). 
The patient was diagnosed with secondary syphilis based on clinical and laboratory findings. He was treated with a single dose of benzathine penicillin G 2.4 million units, intramuscularly. We lost contact with the patient as he did not attend any further appointments. However, the General Directorate of Public Health was informed about the diagnosis of syphilis.

\section{Discussion}

The nodular presentation of secondary syphilis was first described 20 years ago (3). However, nodular secondary syphilis is extremely rare. Veasey et al. reported that there have been only 16 cases with papulonodular secondary syphilis reported in the English medical literature (4). The rare clinical manifestations make the diagnosis of syphilis complicated. The nodular eruption may be red-toviolaceous colored or ulcerated. The lesions tend to affect the face, mucous membranes and palmoplantar region. Fever, arthromyalgia, weight loss, and enlarged lymph nodes may accompany cutaneous findings (3). The differential diagnosis should include sarcoidosis, leprosy, cutaneous lupus erythematous, Sweet's syndrome, disseminated cutaneous leishmaniasis, cutaneous tuberculosis, leukemia and cutaneous lymphoma (4-6). Furthermore, nodular secondary syphilis can be misdiagnosed as syphilitic nodules of the tertiary stage. However, patients with tertiary syphilis usually have the involvement of cardiovascular, central nervous and skeletal systems (7).
The World Health Organization recommends benzathine penicillin G 2.4 million units once intramuscularly in the treatment of early syphilis (8). Besides, patients with nodular secondary syphilis who were treated with administration of benzathine penicillin $\mathrm{G} 2.4$ million units weekly for two or three weeks have been reported (Table 1) $(1-4,6,7,9)$.

The rare clinical manifestations of the disease are usually observed in patients with HIV infection (9). Nevertheless, the patient presented here did not have any coinfections like active hepatitis B, hepatitis C, HSV1, HSV2 or HIV infection. It has been recommended to repeat HIV serology in 2-4 weeks and 3-6 months in suspicious cases (10). Therefore, we suggested rechecking the initial HIV test three months later. As the patient stated that the lesions occurred following antibiotic use, drug eruption was the initial diagnosis. However, detailed clinical history and physical examination helped to determine the necessary laboratory tests in order to reach a definitive diagnosis.

\section{Conclusion}

The patient presented hereby had a rare clinical manifestation of secondary syphilis characterised by multiple, widespread, erythematous nodules and generalised peripheral lymphadenopathy. The diagnosis of uncommon skin lesions in secondary syphilis may be difficult if syphilis is not suspected.

\section{Table 1. Patients with secondary nodular syphilis}

\begin{tabular}{|l|l|l|l|l|l|}
\hline & $\begin{array}{l}\text { age } \\
\text { (years) }\end{array}$ & sex & lesion location & lymphadenopathy & $\begin{array}{l}\text { treatment duration } \\
\text { (BPG 2.4 MU) }\end{array}$ \\
\hline $\begin{array}{l}\text { Dave et al. } \\
(2003)\end{array}$ & 22 & M & face, back, extremities & + & single dose \\
\hline $\begin{array}{l}\text { Hernández-Bel et al. } \\
(2009)\end{array}$ & 58 & M & face, chest & + & 3 weeks \\
\hline $\begin{array}{l}\text { Lee et al. } \\
(2014)\end{array}$ & 44 & F & face, neck, trunk, arms & - & X \\
\hline $\begin{array}{l}\text { Veasey et al. } \\
(2016)\end{array}$ & 63 & M & disseminated & + & 2 weeks \\
\hline $\begin{array}{l}\text { Li et al. } \\
\text { (2017) }\end{array}$ & 51 & M & scalp & + & 3 weeks \\
\hline $\begin{array}{l}\text { Ghafoor et al } \\
\text { (2017) }\end{array}$ & 15 & M & disseminated & + & XX \\
\hline $\begin{array}{l}\text { Magdaleno-Tapial et al. } \\
\text { (2018) }\end{array}$ & 55 & M & face, upper arms, trunk & - & single dose \\
\hline $\begin{array}{l}\text { M: Male } \\
\text { F: Female } \\
\text { BPG 2.4 MU: Benzathine penicillin G 2.4 million units weekly } \\
\text { X: Benzathine penicillin G } 2.4 \text { MU administered intramuscularly. However, the patient developed neurological symptoms and she was } \\
\text { started on crystalline penicillin G. } \\
\text { XX:The patient was treated with benzathine penicillin 1.2 MU. }\end{array}$ & \\
\hline
\end{tabular}


The secondary and tertiary stages of syphilis should always be kept in mind in the differential diagnosis of extensive cutaneous nodules. Early diagnosis and appropriate treatment are crucial to prevent transmission and long-term complications of syphilis.

\section{References}

1. Dave S, Gopinath DV, Thappa DM. Nodular secondary syphilis. Dermatol Online J 2003;9:9. Crossref

2. Magdaleno-Tapial J, Valenzuela-Oñate C, Ortiz-Salvador JM, Hernández-Bel P, Alegre-De Miquel V. Treponema Pallidum epidermotropism in nodular secondary syphilis. Indian J Dermatol 2018;63:509-11. Crossref

3. Hernández-Bel P, López J, Sánchez JL, Alegre V. Nodular secondary syphilis. Actas Dermosifiliogr 2009;100:520-2.

4. Veasey JV, Lellis RF, Boin MF, Porto PL, Chen JC. Papulonodular secondary syphilis: a rare clinic presentation confirmed by serologic and histologic exams. An Bras Dermatol 2016;91:2057. Crossref

5. Dupnik KM, Martins MM, Souza AT, Jerônimo SM, Nobre ML. Nodular secondary syphilis simulating lepromatous leprosy. Lepr Rev 2012;83:389-93.

6. Lee GL, Gru AA, Wong HK, Nagarajan P. Granulomatous syphilis: a pattern to remember. case report and review of literature. Clin Microbial 2015;4:184. Crossref

7. Li F, Wang T, Wang L. Secondary syphilis primarily presenting with multiple nodules on the scalp: case report and published work review. J Dermatol 2017;44:1401-3. Crossref

8. WHO Guidelines for the treatment of Treponema pallidum (Syphilis). Geneva: World Health Organization; 2016. 4, Recommendations for treatment of syphilis. Available from: https://www.ncbi.nIm.nih.gov/books/NBK384905/

9. Ghafoor R, Anwar MI. A young boy with persistent nodules and hoarseness: a rare presentation of nodular secondary syphilis. J Coll Physicians Surg Pak 2018;28:37-8.

10. Edwards B, Vaughan S. HIV testing: support for routine screening. CJGIM 2015;10:20-3. 